Recepción: 20 / 04 / 2017

Aceptación: 20 / 05 / 2017

Publicación: 15 / 06 / 2017
Ciencias de la Educación

Artículo de Revisión

\title{
Actividades de enfoque léxico para aumentar el vocabulario básico de los estudiantes
}

\author{
Lexical approach activities to increase \\ students basic vocabulary
}

\section{Atividades de abordagem lexical para aumentar o vocabulário básico dos alunos}

Olga L. Gonzalez-Ortiz ${ }^{\text {I }}$ gonzalez@utc.edu.ec

Raúl B. Cárdenas-Quintana II raul.cardenas@utc.edu.ec

Marcia J. Chiluisa- Chiluisa III marcia.chuiluisa@utc.edu.ec

Correspondencia: gonzalez@utc.edu.ec

I. PhD.; Licenciada en Ciencias de la Educación Especialidad Ingles; Profesora de Segunda Enseñanza Especialidad Ingles; Doctor en Ciencias Pedagógicas; Doctor en Ciencias Pedagógicas; Magister en Gerencia Educativa; Diploma Superior en Gestión y Planificación Educativa; Universidad Técnica de Cotopaxi, Cotopaxi, Ecuador.

II. PhD.; Profesor de Educación Primaria - Nivel Técnico Superior; Licenciado en Ciencias de la Educación Profesor de Segunda Enseñanza en la Especialización de Castellano y Literatura; Doctor en Ciencias de la Educación Mención Investigación y Planificación Educativa; Doctor en Ciencias Pedagógicas; Magister en Docencia Universitaria y Administración Educativa; Diploma Superior en Didáctica De La Educación Superior; Magister En Ciencias De La Educación Mención Planeamiento y Administración Educativa; Universidad Técnica de Cotopaxi, Cotopaxi, Ecuador.

III. Mg. C.; Licenciada en Ciencias de la Educación Especialización Ingles; Magister en Docencia Universitaria y Administración Educativa; Universidad Técnica de Cotopaxi, Cotopaxi, Ecuador. 


\section{Resumen}

Los estudiantes de la Unidad Educativa de Lenin en el octavo grado enfrentan un serio problema que es la falta de vocabulario.

El vocabulario en inglés es esencial para aprender y enseñar inglés, porque sin un conocimiento suficiente del vocabulario la gente no puede entender a otros ni expresar sus propias ideas. Aunque muchas personas creen erróneamente que el vocabulario de aprendizaje sólo incluye la adquisición de palabras. También incluye fragmentos léxicos y colocaciones, frases de dos o más palabras, como "En mi opinión" (trozos) y "cometer un error" (colocación). Entonces, el vocabulario se puede definir como las palabras de un lenguaje, incluyendo elementos y frases individuales. Hay algunas causas y efectos que son:

Una de las causas es que el profesor no utiliza un material adecuado en el aula. Por lo tanto, los niños no aprenden palabras nuevas. En otras palabras, en el futuro los estudiantes no podrán expresar sus ideas al mismo tiempo que los estudiantes no son capaces de comunicarse en inglés. Otra causa es que el profesor no utiliza buenas estrategias para aumentar el vocabulario en los estudiantes de inglés. Esto es tan difícil porque los estudiantes no pueden comunicarse con sus compañeros y no pueden entender cuando los maestros explican su clase. Otra causa es que los estudiantes no están interesados en aprender nuevas palabras. Esta situación es importante porque los estudiantes no prestan atención a las palabras y no pueden reconocer el significado de las palabras léxicas. Hay investigadores que han trabajado en este problema. Como referencias para resolver el problema hemos tomado el trabajo de estos investigadores: El primero es: (Çakır, 2012) llevó a cabo una investigación cuyo objetivo principal era averiguar si la enseñanza del vocabulario a través de colocaciones resultaría en un mejor aprendizaje del vocabulario que en la enseñanza del vocabulario. En esta investigación utilizó las siguientes preguntas de investigación: ¿La presentación de palabras nuevas a través de colocaciones resulta en un mejor aprendizaje de las palabras que en presentarlas usando técnicas clásicas? ¿La presentación de nuevas palabras a través de colocaciones mejora la retención de nuevos elementos de vocabulario? Él aplicó una metodología cualitativa porque utilizó Pre-prueba / Post-prueba. Utilizó como muestra del estudio a cincuenta y nueve alumnos de séptimo grado de dos aulas en una escuela primaria suburbana de clase media baja en Konya, Turquía. Entonces los participantes se dividieron en dos grupos uno como el grupo de control y el otro como el grupo experimental. En el grupo experimental (7A) había 30 estudiantes 
y en el grupo de control (7B) había 29 estudiantes. El grupo de control se presentó el vocabulario a través de técnicas clásicas como sinónimo, antónimo, definición y equivalencia de la lengua materna, mientras que el grupo experimental se presentó el vocabulario a través de colocaciones. Al final, el investigador encontró que el vocabulario de aprendizaje a través de colocaciones es una estrategia eficaz que contribuye positivamente al desarrollo del aprendizaje de vocabulario y la retención de vocabulario en los estudiantes de inglés en sus mentes por más tiempo. (Páginas 4-9).

La segunda investigación es: (Ajmal y Sita, (2015) realizaron una investigación cuyo objetivo principal fue estudiar el efecto de la enseñanza del vocabulario a través de colocaciones en la mejora del vocabulario de los alumnos del grado 6. En esta investigación se utilizaron las siguientes preguntas de investigación: ¿Cuáles serían los efectos de la enseñanza Vocabulario a través de la colocación en los estudiantes Aplicaron una metodología cualitativa porque usaron el Pre-test / Posttest Utilizaron como una muestra del estudio 36 estudiantes de grado 6 en Baan Koke Sumu, Distrito de Mueang, y la provincia de Narathiwat. De 12 pasajes de lectura que enfatizaron las colocaciones de palabras, cada una de las cuales consistió en el contenido de dos sesiones de 60 minutos cada una de las cuales consistió en tres pasos: presentación, práctica y aplicación, y finalmente los estudiantes obtuvieron un promedio de 11,47 puntos Pretest y un exceso de 16.17 puntos en el posttest en la retención de vocabulario obviamente obtuvieron resultados de éxito con su aplicación (p.1-4).

Palabras claves: Proceso de aprendizaje; vocabulario de ingles; unidades léxicas; vocabulario básico. 


\section{Abstract}

Students at Lenin School Educative Unit in 8th grade face a serious problem that is lack of vocabulary.

English vocabulary is essential for learning and teaching English, because without sufficient knowledge of vocabulary people cannot understand others or express their own ideas. Although many people mistakenly believe that learning vocabulary only includes the acquisition of words. It also includes lexical chunks and collocations, sentences of two or more words, such as "In my opinion" (chunks) and "make a mistake" (collocation). Then, the vocabulary can be defined as the words of a language, including individual elements and phrases. There are some causes and effects which are:

One of the cause is the teacher doesn't use an adequate material in the classroom. Therefore, children don't learn new words. In other words, in the future the students will not be able to express their ideas at the same time students aren't able to communicate in English. Other cause is that teacher doesn't use good strategies to increase vocabulary in English learners. This is so difficult because students cannot communicate with classmates and they cannot understand when teachers explain their class. Another cause is that the students are not interested in learning new words. This situation is important because students don't pay attention to the words and they cannot recognize the lexical words meaning. There are researchers that have worked on this problem. As the references to solve the problem we have taken these researchers' work: The first one is:

(Çakır, 2012)carried out a research whose main aim was to find out whether teaching vocabulary through collocations will result in better vocabulary learning than teaching vocabulary. In this investigation he used the following research questions: Does presenting new words through collocations result in a better learning of the words than presenting them using classical techniques? Do presenting new words through collocations enhance retention of new vocabulary items? $\mathrm{He}$ applied a qualitative methodology because he used Pre-test/Post-test. He used as a sample of the study Fifty nine seventh grade students from two classrooms in a lower-middle class, suburban state primary school in Konya, Turkey. then the participants were divided in two groups one as the control group and the other as the experimental group. In the experimental group (7A) there were 30 students and in the control group (7B) there were 29 students. The control group was presented the vocabulary through classical techniques such as synonym, antonym, definition and mother tongue equivalence while the experimental group was presented the vocabulary through collocations. At the 
end, the researcher found that learning vocabulary through collocations is an effective strategy which positively contributes to the development of vocabulary learning and retention of vocabulary in English learners in their minds longer. (p. 4-9).

The second research is:

(Ajmal \& Sita , (2015) carried out a research whose main aim was to study the effect of teaching vocabulary through collocations on grade 6 learners' vocabulary improvement. In this investigation they used the following research questions: What would be the effects of teaching vocabulary through collocation in students? They applied a qualitative methodology because they used Pretest/Post-test. They used as a sample of the study 36 grade 6 learners at Baan Koke Sumu, Mueang District, and Narathiwat Province. The research instrument consisted of 12 reading passages that emphasized word collocations. Each lesson consisted of the contents for two 60 minute teaching sessions. Each session consisted of three steps: presentation, practice and application. Finally, the results showed that students scored an average of 11.47 points on the pretest and an overage of 16.17 points on the posttest in the vocabulary retention clearly they obtained success results with their application.(p. 1-4).

Key words: learning process; English vocabulary; Lexical units; Basic vocabulary 


\section{Resumo}

Estudantes da Unidade Educativa da Escola de Lenin na $8^{a}$ série enfrentam um grave problema que é falta de vocabulário.

O vocabulário em inglês é essencial para aprender e ensinar inglês, porque sem conhecimento suficiente de vocabulário, as pessoas não conseguem entender os outros ou expressar suas próprias idéias. Embora muitas pessoas acreditem equivocadamente que o vocabulário de aprendizagem inclui apenas a aquisição de palavras. Também inclui pedaços lexicais e colocações, frases de duas ou mais palavras, como "Na minha opinião" (pedaços) e "cometer um erro" (colocação). Então, o vocabulário pode ser definido como as palavras de um idioma, incluindo elementos e frases individuais. Existem algumas causas e efeitos que são:

Uma das causas é que o professor não usa material adequado na sala de aula. Portanto, as crianças não aprendem novas palavras. Em outras palavras, no futuro, os alunos não poderão expressar suas idéias ao mesmo tempo em que os alunos não podem se comunicar em inglês. Outra causa é que o professor não usa boas estratégias para aumentar o vocabulário em aprendizes de inglês. Isso é tão difícil porque os alunos não podem se comunicar com os colegas de classe e não conseguem entender quando os professores explicam sua classe. Outra causa é que os alunos não estão interessados em aprender novas palavras. Esta situação é importante porque os estudantes não prestam atenção às palavras e não podem reconhecer o significado das palavras lexicais. Existem pesquisadores que trabalharam nesse problema. Como referências para resolver o problema, tomamos o trabalho desses pesquisadores: o primeiro é:

(Çakır, 2012) realizou uma pesquisa cujo objetivo principal era descobrir se o ensino do vocabulário através de colocações resultaria em uma melhor aprendizagem do vocabulário do que no ensino do vocabulário. Nesta investigação, ele usou as seguintes questões de pesquisa: apresentar novas palavras através de colocações resultar em uma melhor aprendizagem das palavras do que apresentálas usando técnicas clássicas? Apresentar novas palavras através de colocações melhorar a retenção de novos itens de vocabulário? Ele aplicou uma metodologia qualitativa porque usou pré-teste / pósteste. Ele usou como uma amostra do estudo Cinquenta e nove alunos da sétima série de duas salas de aula em uma escola secundária de classe média baixa, suburbana, em Konya, na Turquia. Então os participantes foram divididos em dois grupos um como grupo controle e o outro como grupo experimental. No grupo experimental (7A) havia 30 alunos e no grupo controle (7B) havia 29 
alunos. O grupo de controle apresentou o vocabulário através de técnicas clássicas como sinônimo, antônimo, definição e equivalência da língua materna, enquanto o grupo experimental apresentou o vocabulário através de colocações. No final, o pesquisador descobriu que aprender vocabulário através de colocações é uma estratégia efetiva que contribui positivamente para o desenvolvimento da aprendizagem de vocabulário e a retenção de vocabulário em aprendizes de inglês em suas mentes por mais tempo. (Pág. 4-9).

A segunda pesquisa é:

Ajmal \& Sita, (2015) realizaram uma pesquisa cujo principal objetivo era estudar o efeito do ensino do vocabulário através de colocações no aprimoramento do vocabulário dos alunos do grau 6. Nesta pesquisa, eles usaram as seguintes questões de pesquisa: quais seriam os efeitos do ensino Vocabulário através da colocação em estudantes? Eles aplicaram uma metodologia qualitativa porque usaram pré-teste / pós-teste. Eles usaram como uma amostra do estudo de alunos do grau 6 em Baan Koke Sumu, distrito de Mueang e da província de Narathiwat. O instrumento de pesquisa consistiu De 12 leituras de leitura que enfatizaram as colocações de palavras. Cada lição consistiu no conteúdo de duas sessões de ensino de 60 minutos. Cada sessão consistiu em três etapas: apresentação, prática e aplicação. Finalmente, os resultados mostraram que os alunos obtiveram uma média de 11,47 pontos no Pré-teste e um excesso de 16,17 pontos no pós-teste na retenção de vocabulário claramente obtiveram resultados de sucesso com sua aplicação (p. 1-4).

Palavras-chave: proceso de aprendizagem; Vocabulario de ingles; Unidades léxicas; Vocabulario básico. 


\section{Introducción.}

Nowadays, the investigation of teaching learning process about vocabulary as second language has had more influence into the acquisition of English vocabulary.

This investigation has significant importance into improving the quality of learning English language. Through the investigation of that problem we could know more about students' deficiency or lack of vocabulary knowledge in 8th year GBE at Lenin School. Moreover, the implementations of activities based in lexical approach (collocations) allow students acquire more vocabulary which is the base to improve communicative competence. Teacher can show students how lexical units or basic vocabulary that they know can be combined to form phrases that can be used to make sentences and produce speaking language.

In addition, it will be useful to the teachers so that increase the quality of teaching-learning process in the institution. In this context the role of vocabulary is essential because "without grammar we can communicate but without vocabulary nothing” (Lessard-Clouston, 1994, p. 1). recovered from http://files.eric.ed.gov/fulltext/EJ499453.pdf Clearly, it involves that with the appropriate vocabulary knowledge students will be able to learn acquire vocabulary and improve the speaking skill in the best way.

In this search project we had applied the lexical collocation activities which basically were based in the use of base vocabulary that students had acquired as long of their academic studies also how to combine words into phrases to communicate a massage effectively. That's why improving vocabulary is important into learning English language. The application of this activities are fairly beneficial for students because with this useful and newfangled. Overall, students learn and are able 
to use the combination of words that they find on their books and use them to speak with classmates and English teacher.

\section{Materiales y métodos.}

\begin{tabular}{|c|c|c|c|}
\hline OBJECTIVES & ACTIVITY & RESULT & METHODODOGY \\
\hline $\begin{array}{l}\text { To analyze the role and principles of } \\
\text { lexical approach in vocabulary learning } \\
\text { through the literature review to select } \\
\text { the activities that will be applied. }\end{array}$ & Literature review & $\begin{array}{l}\text { Language } \\
\text { activities plan }\end{array}$ & Analytical method. \\
\hline $\begin{array}{l}\text { - To implement language activities based } \\
\text { in lexical approach in } 8^{\text {th }} \text { graders in the } \\
\text { class to motivate students learn more } \\
\text { vocabulary. }\end{array}$ & $\begin{array}{l}\text { Apply action } \\
\text { plan }\end{array}$ & $\begin{array}{l}\text { Vocabulary } \\
\text { improvement }\end{array}$ & Action research. \\
\hline $\begin{array}{l}\text { To evaluate language activities } \\
\text { implementation based on lexical } \\
\text { approach with the application of a test } \\
\text { to identify what are the results of the } \\
\text { activities implementation. }\end{array}$ & $\begin{array}{l}\text { Apply the } \\
\text { Questionary }\end{array}$ & $\begin{array}{l}\text { Students' } \\
\text { improvement. }\end{array}$ & Test. \\
\hline
\end{tabular}

TABLE 1

ACTIVITIES AND TASKS SYSTEM REGARDING THE OBJECTIVES RAISED

Si aplica por el tipo de investigación 


\section{Resultados.}

\section{DATA ANALYSIS AND INTERPRETATION}

\section{PRE-TEST}

The instruction was: You must choose between these two phrases: "I know the phrase" or "I don't know the phrase" and write the meaning if you know the phrase.

\begin{tabular}{|l|l|}
\hline I know the phrase & 0 \\
\hline I don't know the phrase & 8 \\
\hline TOTAL & 8 \\
\hline
\end{tabular}

Table2: Come from

Source: 8 Graders from "Lenin School" Educative Unit

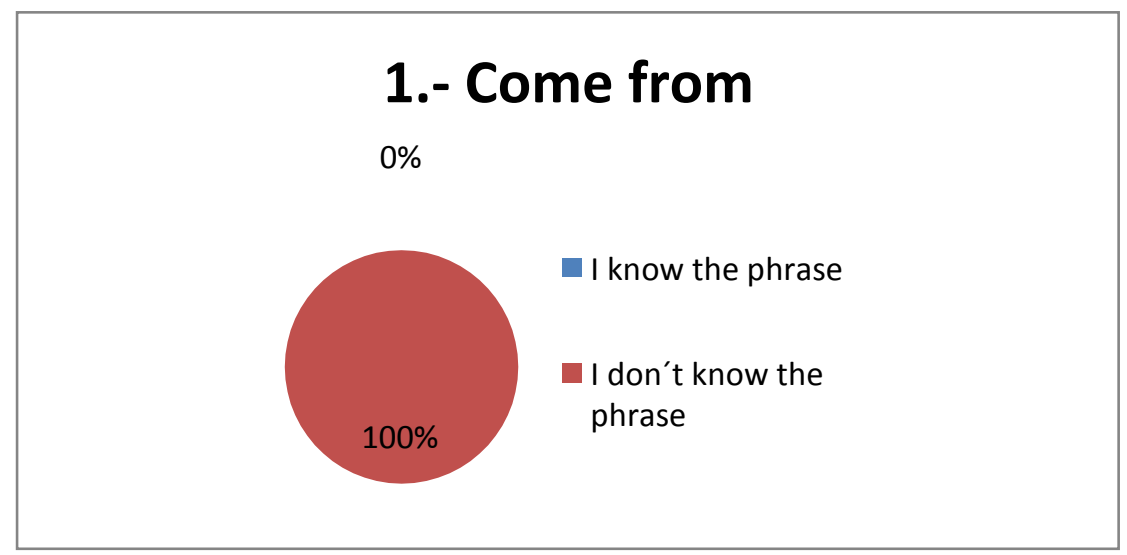

Imagen1: Come from

Source: 8 Graders from "Lenin School" Educative Unit

\section{INTERPRETATION:}

From eight evaluated students, 8 students say that they do not know the collocation come from corresponding to $100 \%$ of the sample. 
Actividades de enfoque léxico para aumentar el vocabulario

\begin{tabular}{|l|l|}
\hline I know the phrase & 1 \\
\hline I don't know the phrase & 7 \\
\hline TOTAL & 8 \\
\hline
\end{tabular}

Table3: Live with

Source: 8 Graders from "Lenin School" Educative Unit

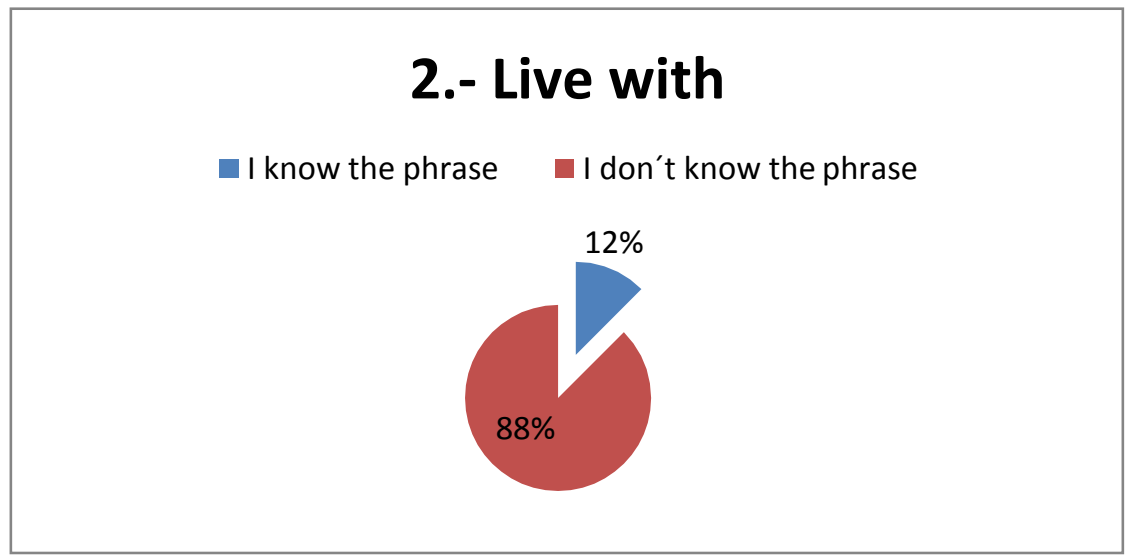

Table2: Live with

Source: 8 Graders from "Lenin School" Educative Unit

INTERPRETATION:

From eight evaluated students, 7 students say that they do not know the collocation live with corresponding to $88 \%$ while 1 student says that know the collocation corresponding to $12 \%$ of the sample.

\begin{tabular}{|l|l|}
\hline I know the phrase & 0 \\
\hline I don't know the phrase & 8 \\
\hline TOTAL & 8 \\
\hline
\end{tabular}

Table4: Shake hands

Source: 8 Graders from "Lenin School" Educative Unit 


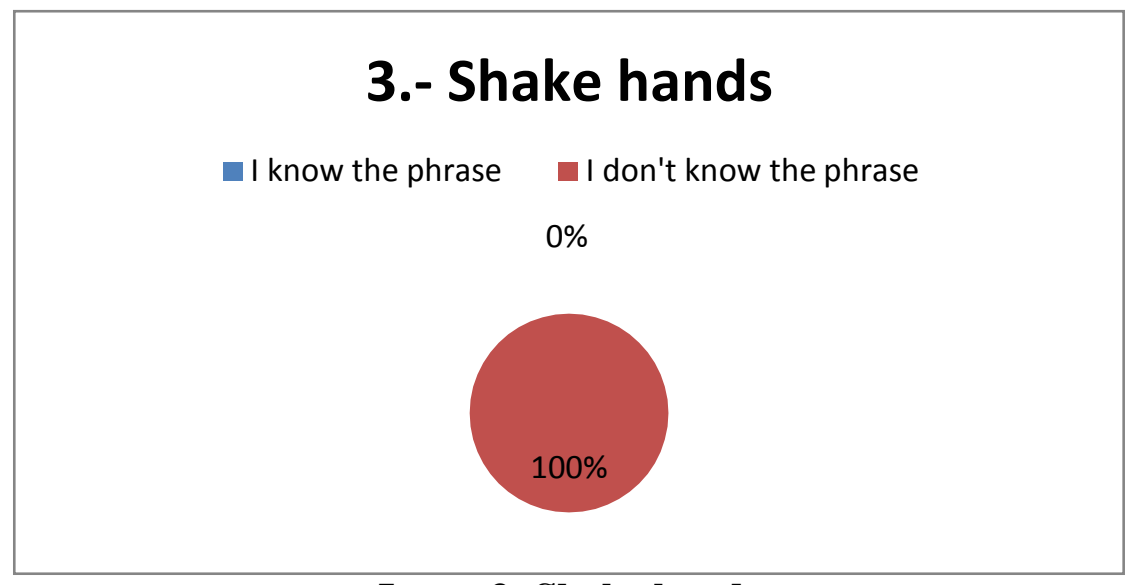

Image 3: Shake hands

Source: 8 Graders from "Lenin School" Educative Unit

\section{INTERPRETATION:}

From eight evaluated students, 8 students say that they do not know the collocation shake hands corresponding to $100 \%$ of the sample.

\begin{tabular}{|l|l|}
\hline I know the phrase & 1 \\
\hline I don't know the phrase & 7 \\
\hline TOTAL & 8 \\
\hline
\end{tabular}

Table5: New home

Source: 8 Graders from "Lenin School" Educative Unit

\section{4.-New home}

I know the phrase I Don't know the phrase

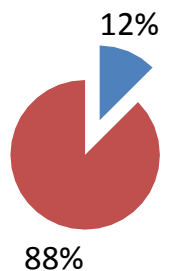

Image4: New home

Source: 8 Graders from "Lenin School" Educative Unit 


\section{INTERPRETATION:}

From eight evaluated students, 7 students say that they do not know the collocation new home corresponding to $88 \%$ while 1 student says that know the collocation corresponding to $12 \%$ of the sample.

\begin{tabular}{|l|l|}
\hline I know the phrase & 0 \\
\hline I don't know the phrase & 8 \\
\hline TOTAL & 8 \\
\hline
\end{tabular}

Table6: Go out

Source: 8 Graders from "Lenin School" Educative Unit

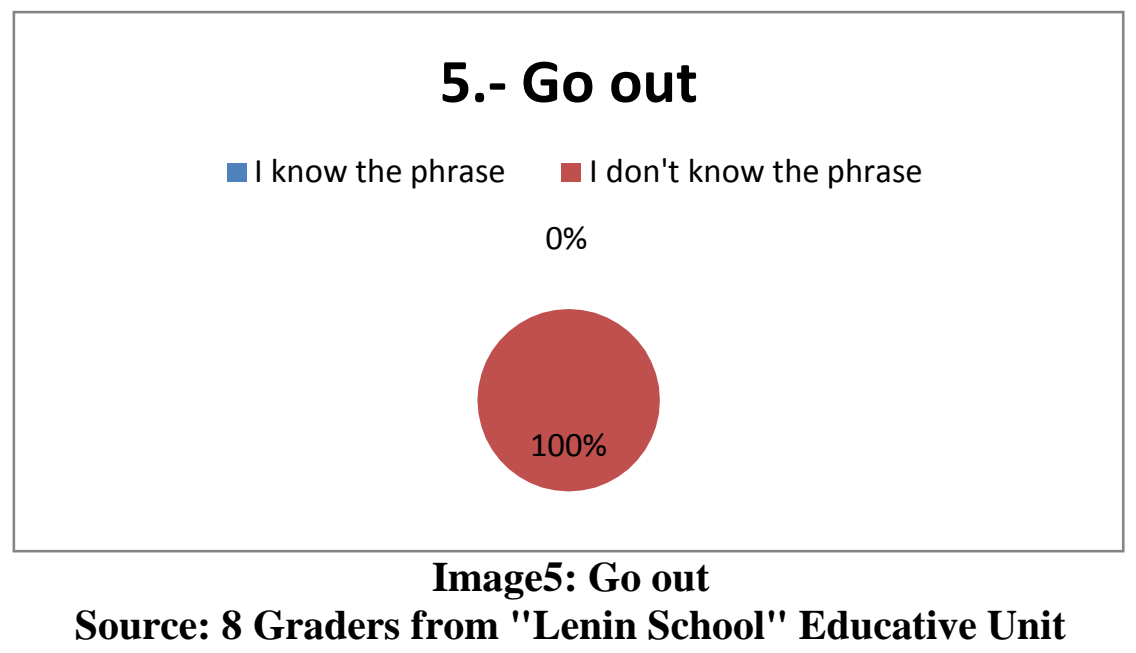

INTERPRETATION:

From eight evaluated students, 8 students say that they do not know the collocation go out corresponding to $100 \%$ of the sample. 
Olga L. Gonzales-Ortiz; Raúl B. Cárdenas-Quintana; Marcia J. Chiluisa- Chiluisa

\begin{tabular}{|l|l|}
\hline I know the phrase & 1 \\
\hline I don't know the phrase & 7 \\
\hline TOTAL & 8 \\
\hline
\end{tabular}

Table7: Take a shower

Source: 8 Graders from "Lenin School" Educative Unit

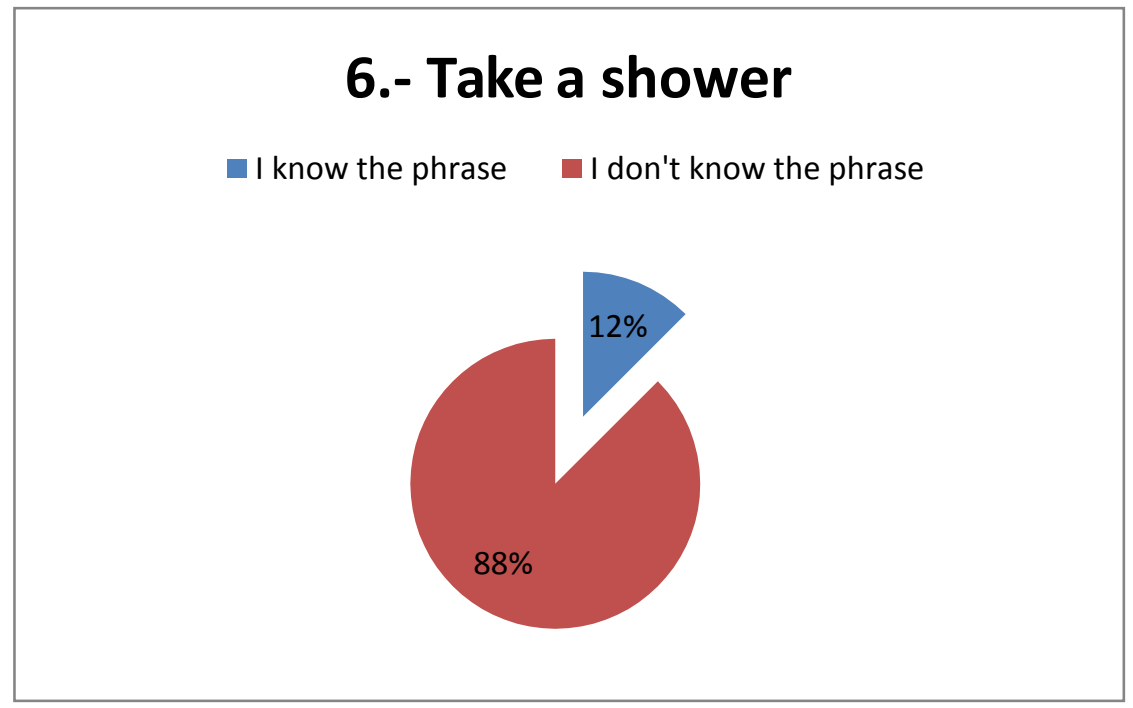

Image6: Take a shower

Source: 8 Graders from "Lenin School" Educative Unit

INTERPRETATION:

From eight evaluated students, 7 students say that they do not know the collocation take a shower corresponding to $88 \%$ while 1 student says that know the collocation corresponding to $12 \%$ of the sample.

\begin{tabular}{|l|l|}
\hline I know the phrase & 0 \\
\hline I don't know the phrase & 8 \\
\hline TOTAL & 8 \\
\hline
\end{tabular}

Table8: On time

Source: 8 Graders from "Lenin School" Educative Unit 


\section{7.- On time}
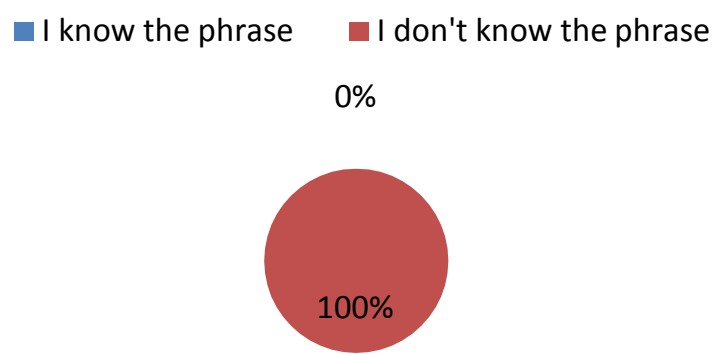

Image7: On time

Source: 8 Graders from "Lenin School" Educative Unit

INTERPRETATION:

From eight evaluated students, 8 students say that they do not know the collocation on time corresponding to $100 \%$ of the sample.

\begin{tabular}{|l|l|}
\hline I know the phrase & 0 \\
\hline I don't know the phrase & 8 \\
\hline TOTAL & 8 \\
\hline
\end{tabular}

Table9: Noisy neighborhood

Source: 8 Graders from "Lenin School" Educative Unit

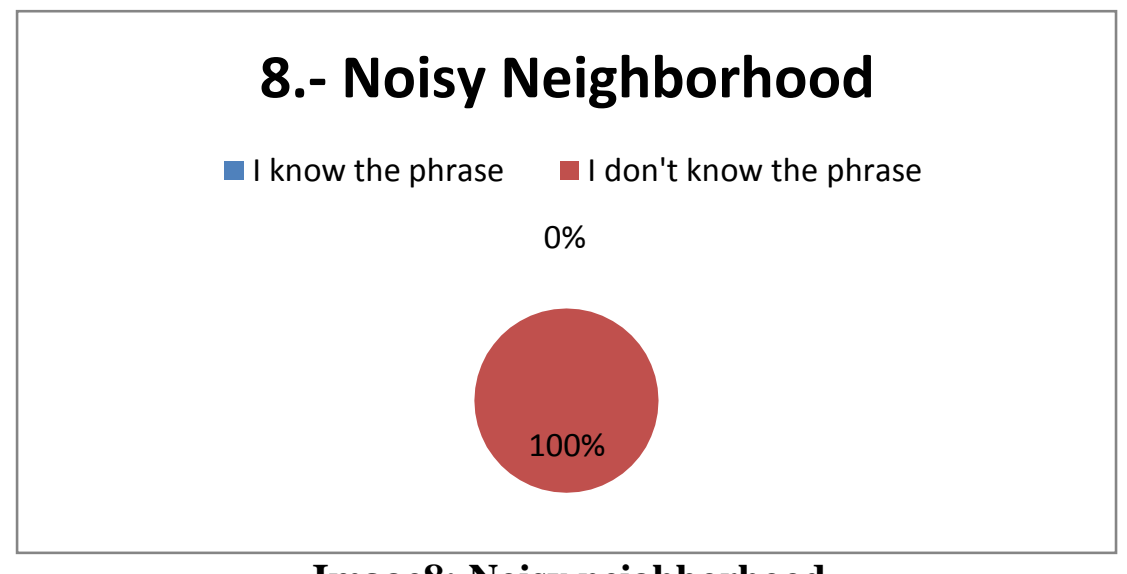

Image8: Noisy neighborhood

Source: 8 Graders from "Lenin School" Educative Unit 


\section{INTERPRETATION:}

From eight evaluated students, 8 students say that they do not know the collocation Noisy Neighborhood corresponding to $100 \%$ of the sample.

\begin{tabular}{|l|l|}
\hline I know the phrase & 0 \\
\hline I don't know the phrase & 8 \\
\hline TOTAL & 8 \\
\hline
\end{tabular}

Table10: Tourist town

Source: 8 Graders from "Lenin School" Educative Unit

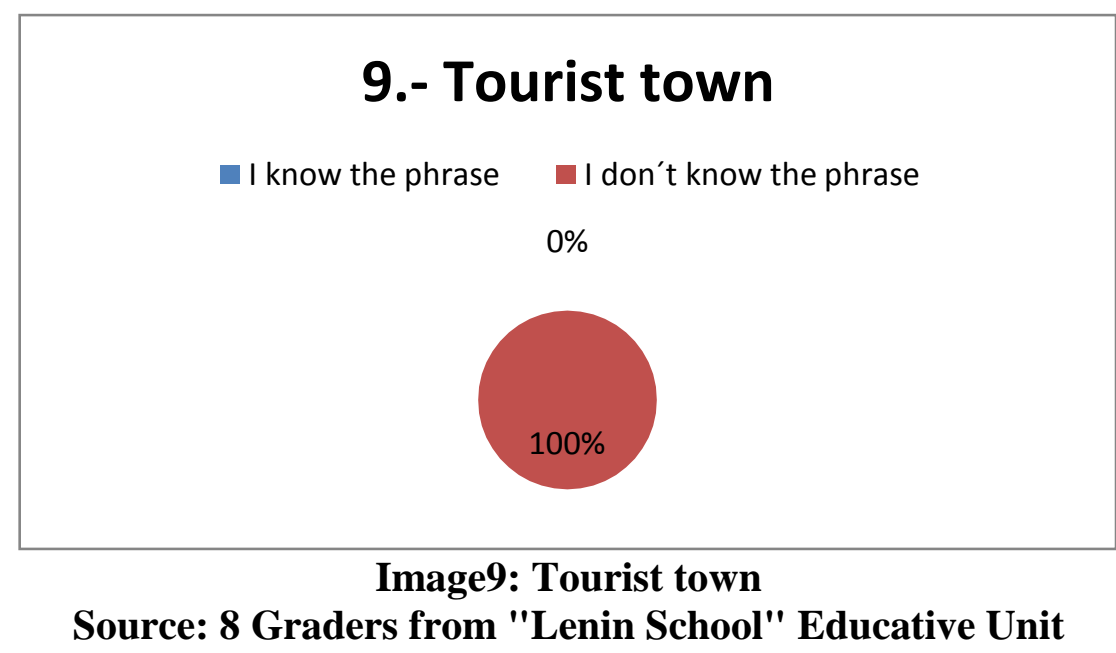

INTERPRETATION:

From eight evaluated students, 8 students say that they do not know the collocation Tourist town corresponding to $100 \%$ of the sample. 


\begin{tabular}{|l|l|}
\hline I know the phrase & 0 \\
\hline I don't know the phrase & 8 \\
\hline TOTAL & 8 \\
\hline
\end{tabular}

Table11: Strong bones

Source: 8 Graders from "Lenin School" Educative Unit

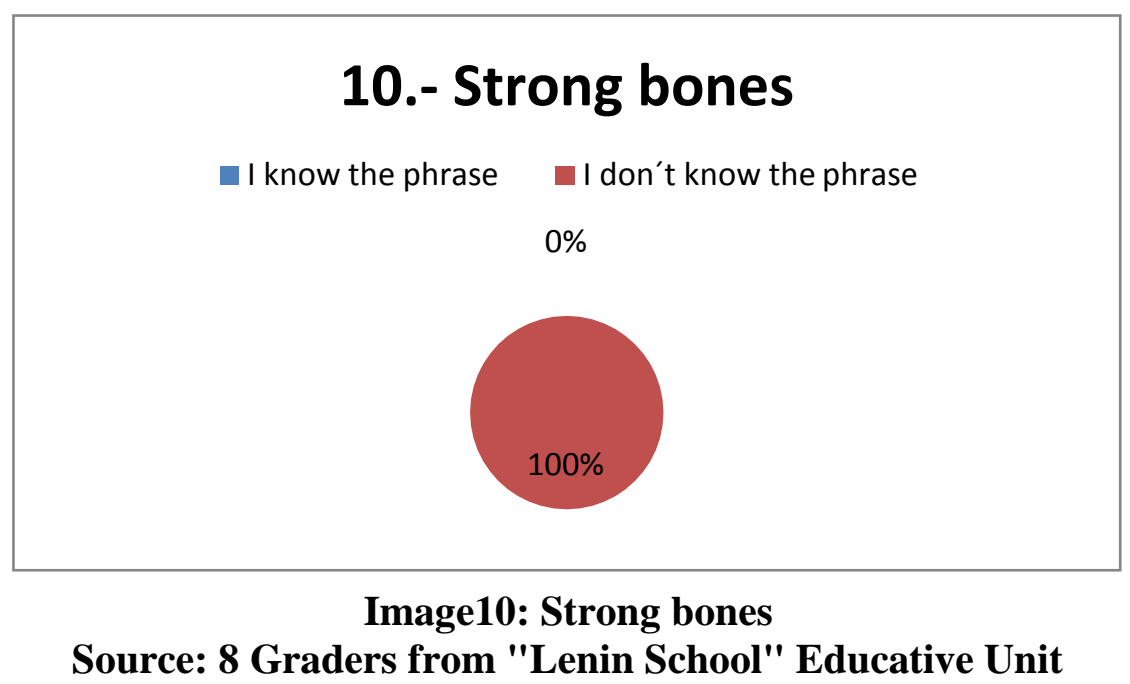

INTERPRETATION:

From eight evaluated students, 8 students say that they do not know the collocation strong bones corresponding to $100 \%$ of the sample.

\begin{tabular}{|l|l|}
\hline I know the phrase & 0 \\
\hline I don't know the phrase & 8 \\
\hline TOTAL & 8 \\
\hline
\end{tabular}

Table12: Eat too

Source: 8 Graders from "Lenin School" Educative Unit 


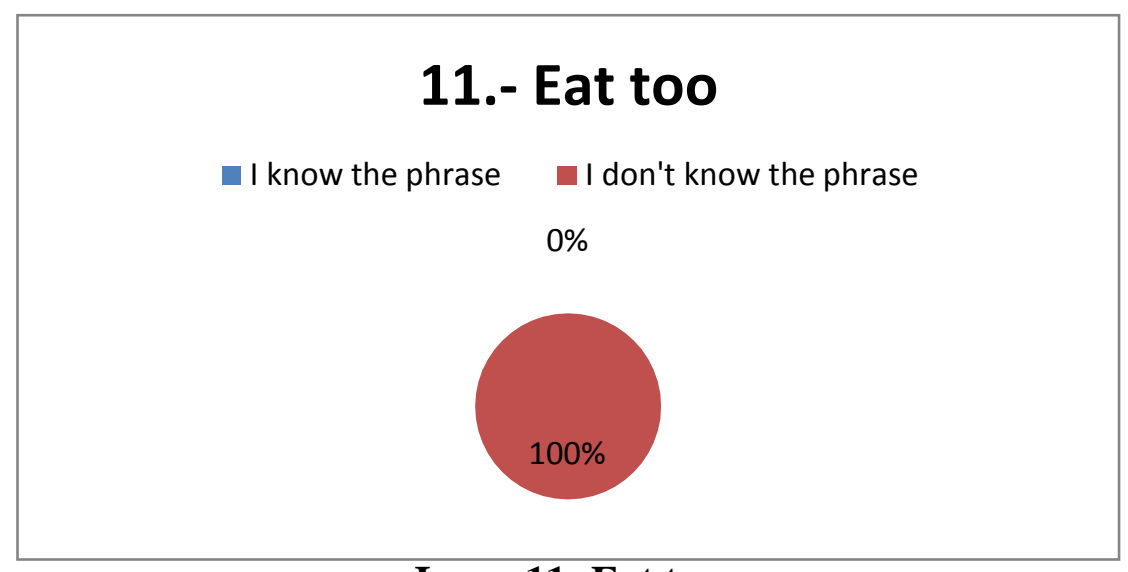

Image11: Eat too

Source: 8 Graders from "Lenin School" Educative Unit

INTERPRETATION:

From eight evaluated students, 8 students say that they do not know the collocation eat too corresponding to $100 \%$ of the sample.

\begin{tabular}{|l|l|}
\hline I know the phrase & 1 \\
\hline I don't know the phrase & 7 \\
\hline TOTAL & 8 \\
\hline
\end{tabular}

Table13: Nice trip

Source: 8 Graders from "Lenin School" Educative Unit

\section{2.-Nice trip}

I know the phrase I don't know the phrase

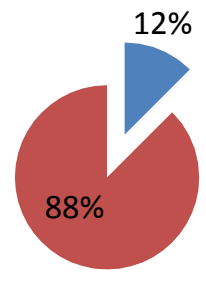

\section{Image12: Nice trip}

Source: 8 Graders from "Lenin School" Educative Unit 
INTERPRETATION:

From eight evaluated students, 7 students say that they do not know the collocation nice trip corresponding to $88 \%$ while 1 student says that know the collocation corresponding to $12 \%$ of the sample.

\begin{tabular}{|l|l|}
\hline I know the phrase & 1 \\
\hline I don't know the phrase & 7 \\
\hline TOTAL & 8 \\
\hline
\end{tabular}

Table14: Come here

Source: 8 Graders from "Lenin School" Educative Unit

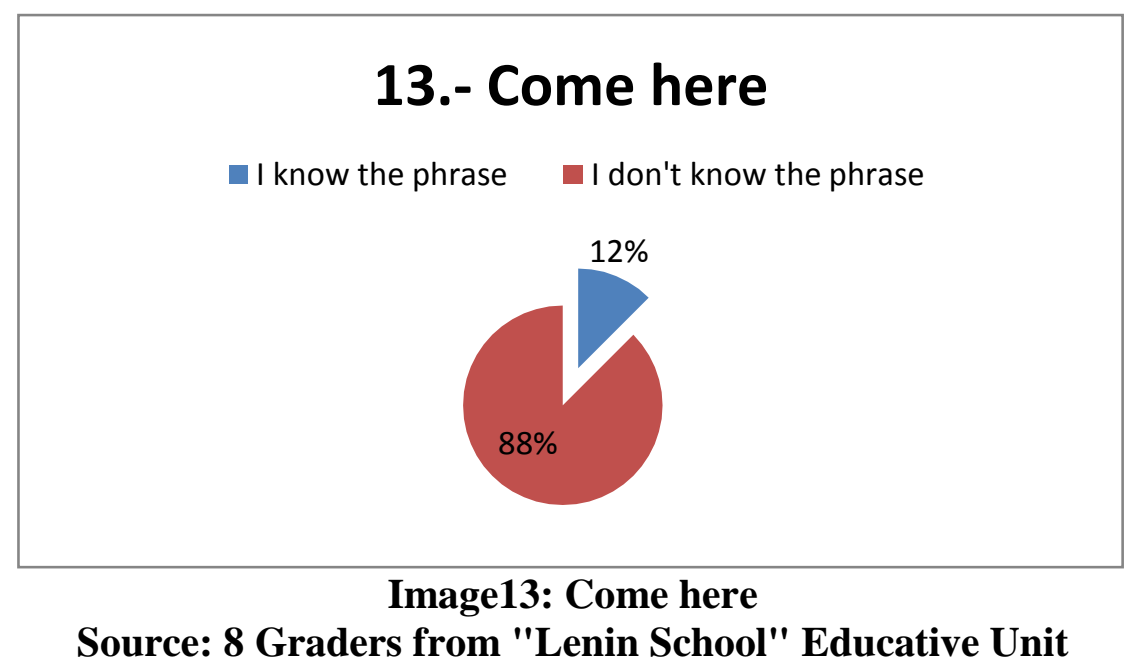

INTERPRETATION:

From eight evaluated students, 7 students say that they do not know the collocation come here corresponding to $88 \%$ while 1 student says that know the collocation corresponding to $12 \%$ of the sample. 
Olga L. Gonzales-Ortiz; Raúl B. Cárdenas-Quintana; Marcia J. Chiluisa- Chiluisa

\begin{tabular}{|l|l|}
\hline I know the phrase & 0 \\
\hline I don't know the phrase & 8 \\
\hline TOTAL & 8 \\
\hline
\end{tabular}

Table15: Warm clothes

Source: 8 Graders from "Lenin School" Educative Unit

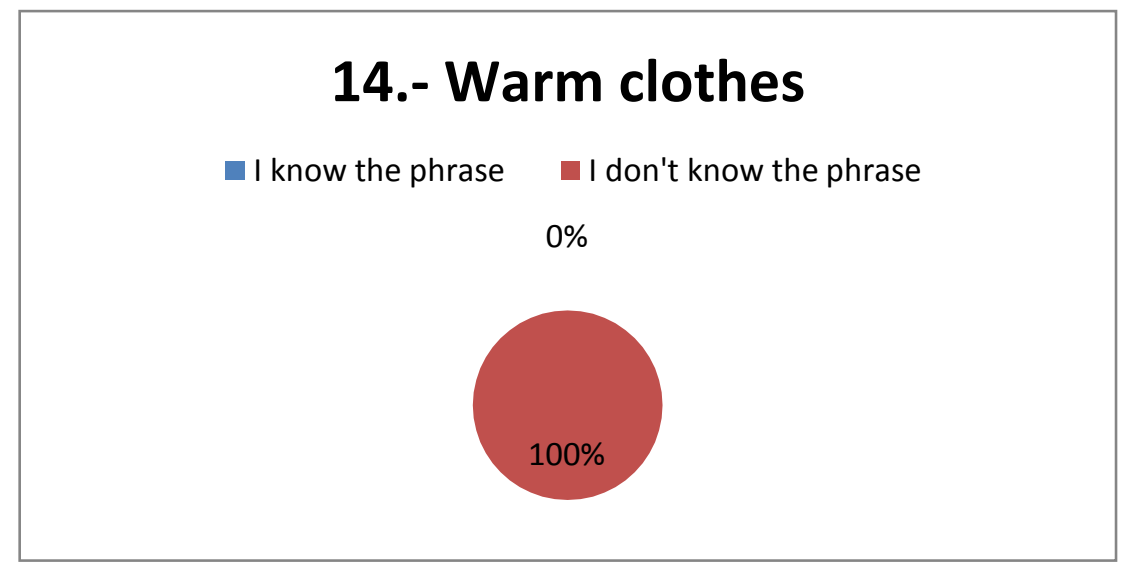

Image14: Warm clothes

Source: 8 Graders from "Lenin School" Educative Unit

INTERPRETATION:

From eight evaluated students, 8 students say that they do not know the collocation warm clothes corresponding to $100 \%$ of the sample.

\begin{tabular}{|l|l|}
\hline I know the phrase & 1 \\
\hline I don't know the phrase & 7 \\
\hline TOTAL & 8 \\
\hline
\end{tabular}

Table16: Christmas present

Source: 8 Graders from "Lenin School" Educative Unit 


\section{5.- Christmas present}

I know the phrase I don't know the phrase

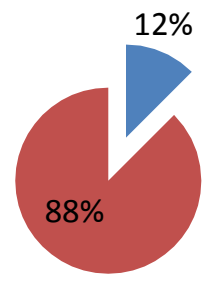

Image15: Christmas present

Source: 8 Graders from "Lenin School" Educative Unit

\section{INTERPRETATION:}

From eight evaluated students, 7 students say that they do not know the collocation christmas present corresponding to $88 \%$ while 1 student says that know the collocation corresponding to $12 \%$ of the sample. 
Olga L. Gonzales-Ortiz; Raúl B. Cárdenas-Quintana; Marcia J. Chiluisa- Chiluisa

\begin{tabular}{|l|l|}
\hline I know the phrase & 0 \\
\hline I don't know the phrase & 8 \\
\hline TOTAL & 8 \\
\hline
\end{tabular}

Table17: Exchange presents

Source: 8 Graders from "Lenin School" Educative Unit

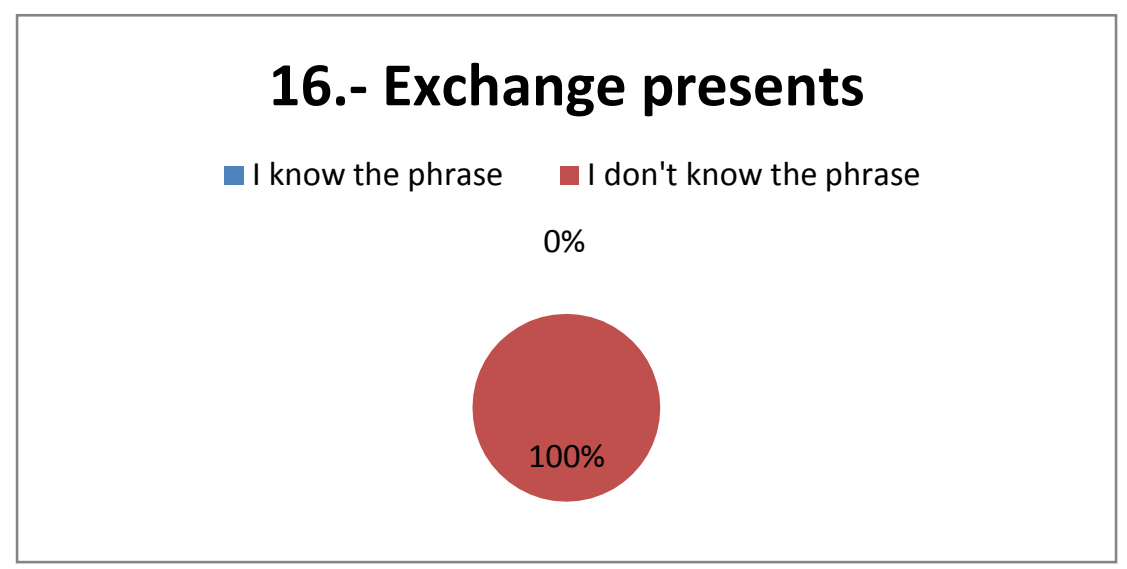

Image16: Exchange presents

Source: 8 Graders from "Lenin School" Educative Unit

INTERPRETATION:

From eight evaluated students, 8 students say that they do not know the collocation Exchange presents corresponding to $100 \%$ of the sample. 


\begin{tabular}{|l|l|}
\hline I know the phrase & 1 \\
\hline I don't know the phrase & 7 \\
\hline TOTAL & 8 \\
\hline
\end{tabular}

Table18: Free time

Source: 8 Graders from "Lenin School" Educative Unit

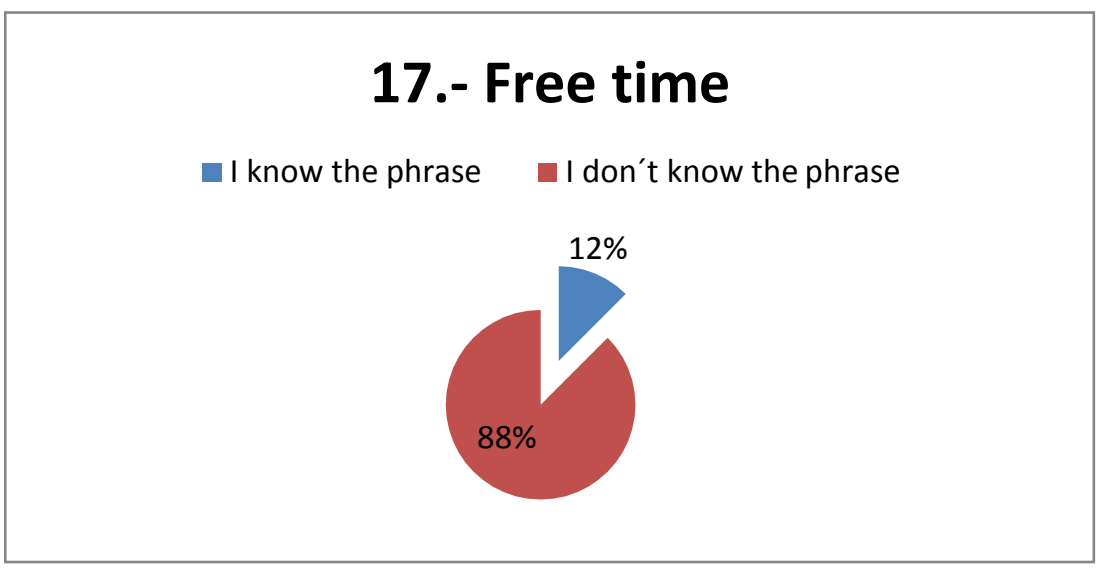

Image17: Free time

Source: 8 Graders from "Lenin School" Educative Unit

INTERPRETATION:

From eight evaluated students, 7 students say that they do not know the collocation free time corresponding to $88 \%$ while 1 student says that know the collocation corresponding to $12 \%$ of the sample.

\begin{tabular}{|l|l|}
\hline I know the phrase & 2 \\
\hline I don't know the phrase & 6 \\
\hline TOTAL & 8 \\
\hline
\end{tabular}

Table19: Under water

Source: 8 Graders from "Lenin School" Educative Unit 
Olga L. Gonzales-Ortiz; Raúl B. Cárdenas-Quintana; Marcia J. Chiluisa- Chiluisa

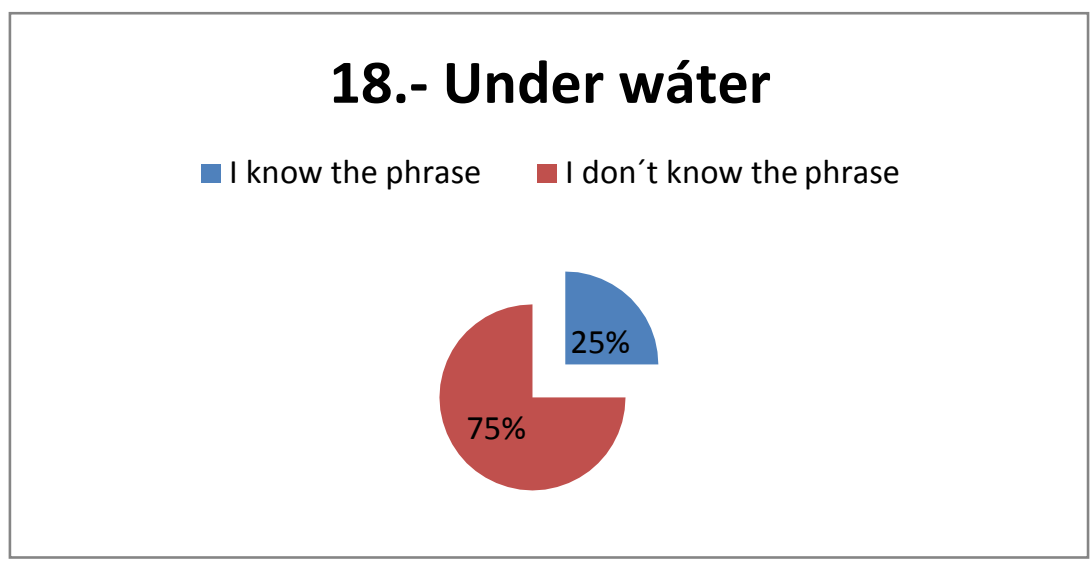

Imagr18: Under water

Source: 8 Graders from "Lenin School" Educative Unit

INTERPRETATION:

From eight evaluated students, 6 students say that they do not know the collocation under water corresponding to $75 \%$ while 2 students say that know the collocation corresponding to $25 \%$ of the sample.

\begin{tabular}{|l|l|}
\hline I know the phrase & 4 \\
\hline I don't know the phrase & 4 \\
\hline TOTAL & 8 \\
\hline
\end{tabular}

Table20: True friend

Source: 8 Graders from "Lenin School" Educative Unit 


\section{9.- True friend}

I know the phrase I don't know the phrase

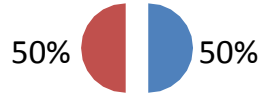

Image19: True friend

Source: 8 Graders from "Lenin School" Educative Unit

\section{INTERPRETATION:}

From eight evaluated students, 4 students say that they do not know the collocation true friend corresponding to $50 \%$ while 4 students say that know the collocation corresponding to $50 \%$ of the sample.

\begin{tabular}{|l|l|}
\hline I know the phrase & 2 \\
\hline I don't know the phrase & 6 \\
\hline TOTAL & 8 \\
\hline
\end{tabular}

Table21: Human voice

Source: 8 Graders from "Lenin School" Educative Unit

\section{0.-Human voice}

I know the phrase I Don't know the phrase

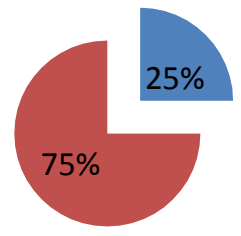

Image 20: Human voice

Source: 8 Graders from "Lenin School" Educative Unit 


\section{INTERPRETATION:}

From eight evaluated students, 6 students say that they do not know the collocation human voice corresponding to $75 \%$ while 2 students say that know the collocation corresponding to $25 \%$ of the sample.

\section{DATA ANALYSIS AND INTERPRETATION}

\section{POST-TEST}

The instruction was: You must choose between these two phrases: "I know the phrase" or "I don't know the phrase" and write the meaning if you know the phrase.

\begin{tabular}{|l|l|}
\hline I know the phrase & 6 \\
\hline I don't know the phrase & 2 \\
\hline TOTAL & 8 \\
\hline
\end{tabular}

Table22: Come from

Source: 8 Graders from "Lenin School" Educative Unit

\section{1.- Come from}

I know the phrase I don't know the phrase

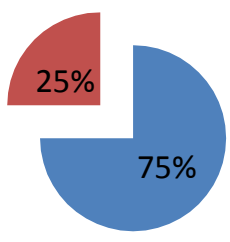

\section{Image21: Come from}

Source: 8 Graders from "Lenin School" Educative Unit 
INTERPRETATION:

From eight evaluated students, 2 students say that they do not know the collocation come from corresponding to $25 \%$ while 6 students say that know the collocation corresponding to $75 \%$ of the sample.

\begin{tabular}{|l|l|}
\hline I know the phrase & 8 \\
\hline I don't know the phrase & 0 \\
\hline TOTAL & 8 \\
\hline
\end{tabular}

Table23: Live with

Source: 8 Graders from "Lenin School" Educative Unit

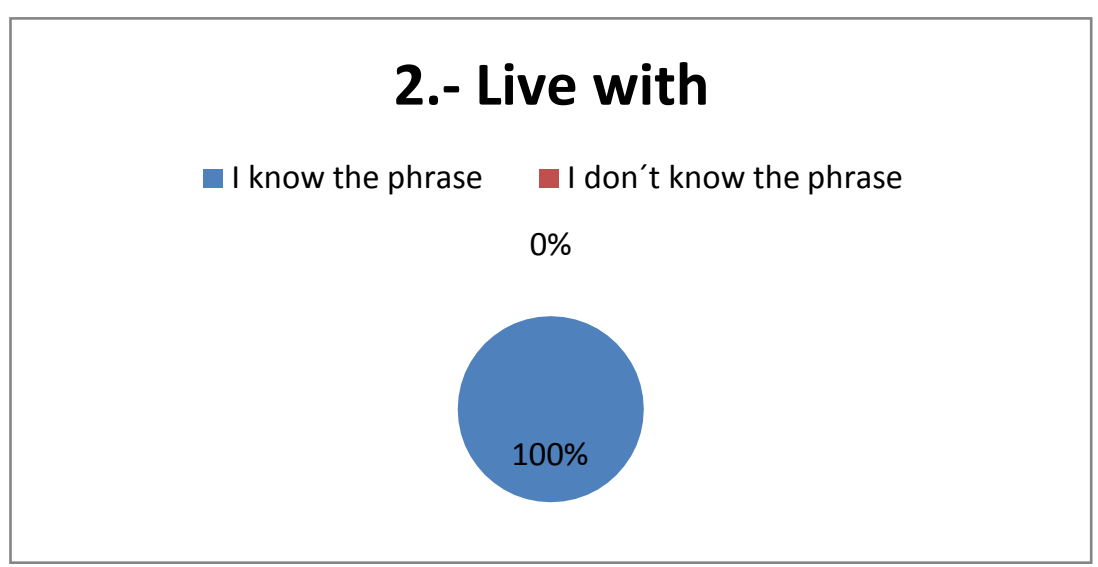

Image22: Live with

Source: 8 Graders from "Lenin School" Educative Unit

INTERPRETATION:

From eight evaluated students, 8 students say that know the collocation live with corresponding to $100 \%$ of the sample. 
Olga L. Gonzales-Ortiz; Raúl B. Cárdenas-Quintana; Marcia J. Chiluisa- Chiluisa

\begin{tabular}{|l|l|}
\hline I know the phrase & 1 \\
\hline I don't know the phrase & 7 \\
\hline TOTAL & 8 \\
\hline
\end{tabular}

Table24: Shake hands

Source: 8 Graders from "Lenin School" Educative Unit

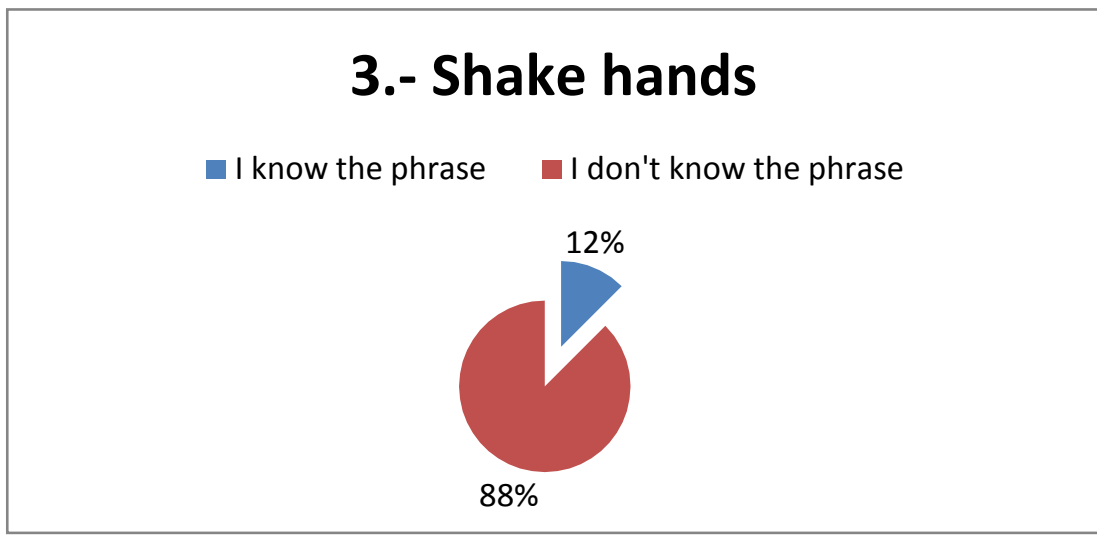

\section{Image23: Shake hands}

Source: 8 Graders from "Lenin School" Educative Unit

\section{INTERPRETATION:}

From eight evaluated students, 7 students say that they do not know the collocation shake hands corresponding to $88 \%$ while 1 student says that know the collocation corresponding to $12 \%$ of the sample.

\begin{tabular}{|l|l|}
\hline I know the phrase & 8 \\
\hline I don't know the phrase & 0 \\
\hline TOTAL & 8 \\
\hline
\end{tabular}

Table25: New home

Source: 8 Graders from "Lenin School" Educative Unit 


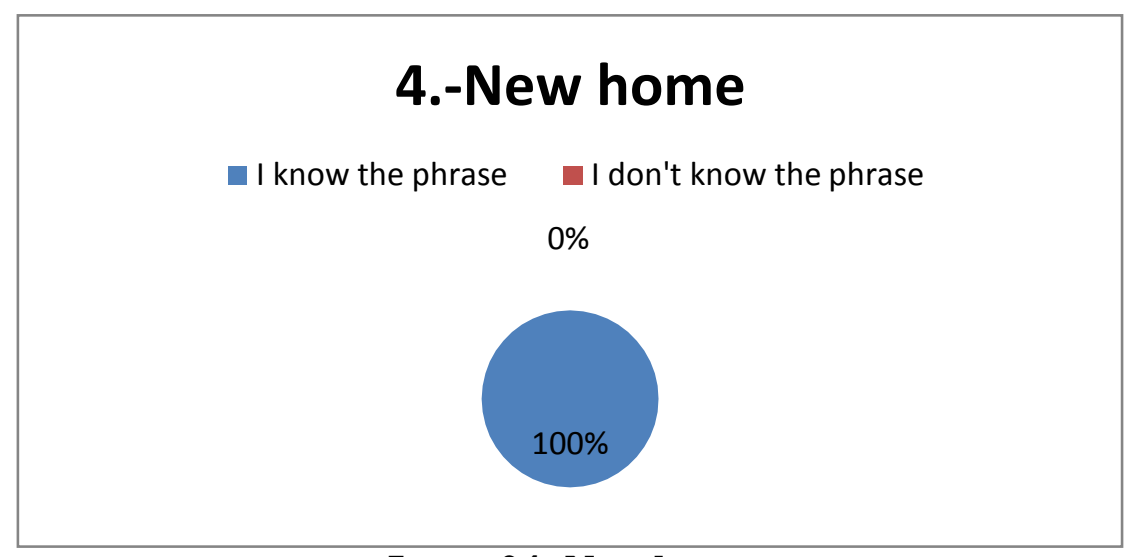

Image24: New home

Source: 8 Graders from "Lenin School" Educative Unit

INTERPRETATION:

From eight evaluated students, 8 students say that know the collocation new home corresponding to $100 \%$ of the sample.

\begin{tabular}{|l|l|}
\hline I know the phrase & 6 \\
\hline I don't know the phrase & 2 \\
\hline TOTAL & 8 \\
\hline
\end{tabular}

Table26: Go out

Source: 8 Graders from "Lenin School" Educative Unit

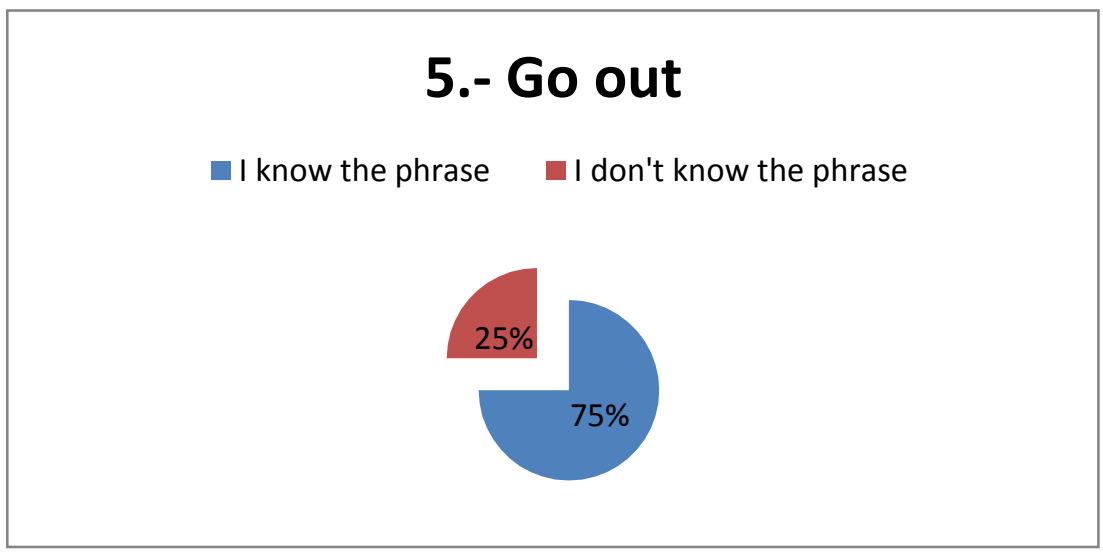

Image25: Go out

Source: 8 Graders from "Lenin School" Educative Unit 


\section{INTERPRETATION:}

From eight evaluated students, 2 students say that they do not know the collocation go out corresponding to $25 \%$ while 6 students say that know the collocation corresponding to $75 \%$ of the sample.

\begin{tabular}{|l|l|}
\hline I know the phrase & 7 \\
\hline I don't know the phrase & 1 \\
\hline TOTAL & 8 \\
\hline
\end{tabular}

Table27: Take a shower

Source: 8 Graders from "Lenin School" Educative Unit

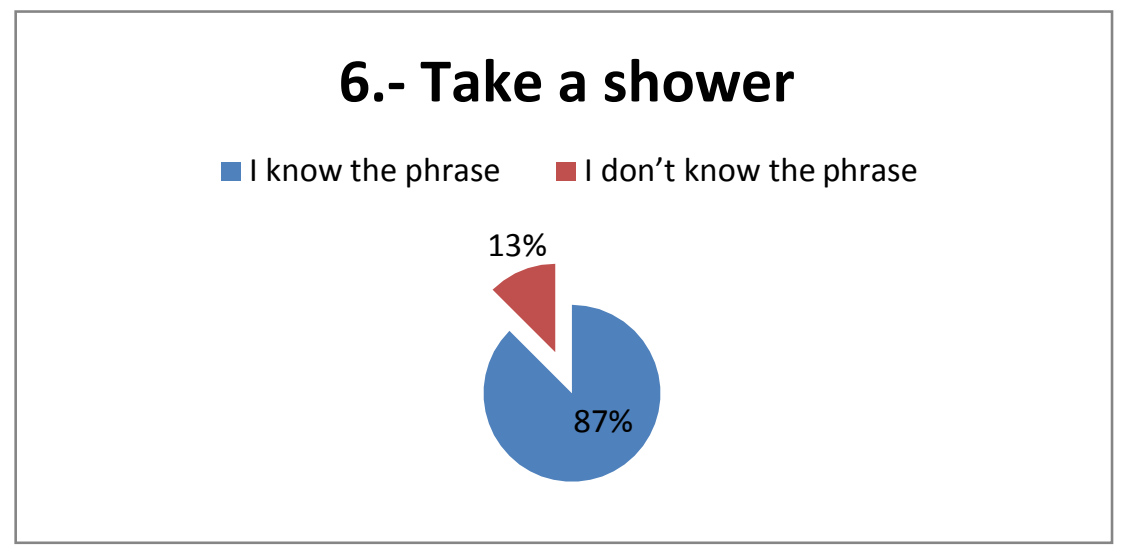

Image26: Take a shower

Source: 8 Graders from "Lenin School" Educative Unit

INTERPRETATION:

From eight evaluated students, 1 student says that they do not know the collocation take a shower corresponding to $13 \%$ while 7 students say that know the collocation corresponding to $87 \%$ of the sample. 
Actividades de enfoque léxico para aumentar el vocabulario

\begin{tabular}{|l|l|}
\hline I know the phrase & 5 \\
\hline I don't know the phrase & 3 \\
\hline TOTAL & 8 \\
\hline
\end{tabular}

Table28: On time

Source: 8 Graders from "Lenin School" Educative Unit

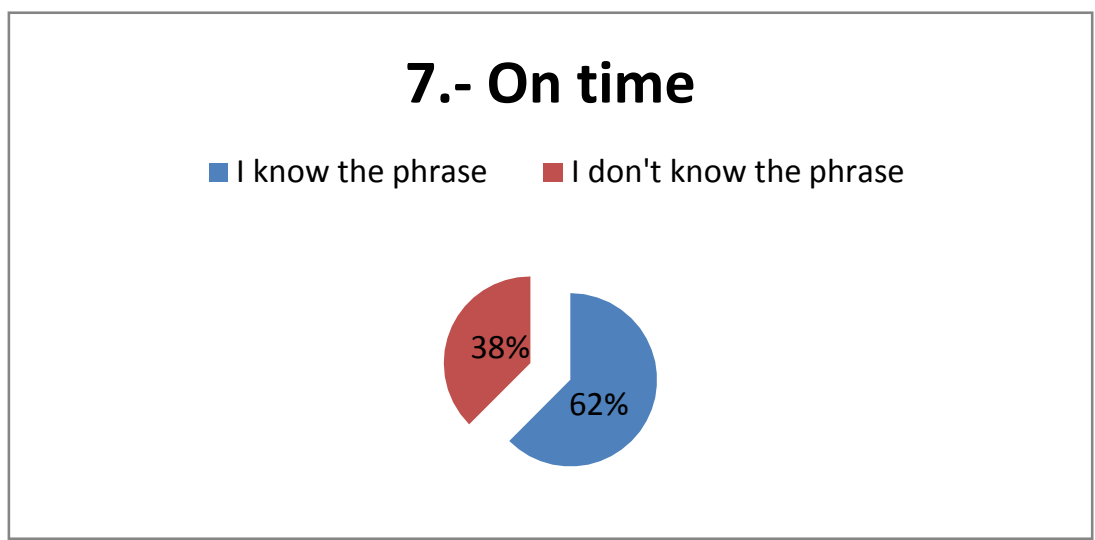

Image27: On time

Source: 8 Graders from "Lenin School" Educative Unit

INTERPRETATION:

From eight evaluated students, 3 students say that they do not know the collocation on time corresponding to $38 \%$ while 5 students say that know the collocation corresponding to $62 \%$ of the sample.

\begin{tabular}{|l|l|}
\hline I know the phrase & 1 \\
\hline I don't know the phrase & 7 \\
\hline TOTAL & 8 \\
\hline
\end{tabular}

Table29: Noisy neighborhood

Source: 8 Graders from "Lenin School" Educative Unit 


\section{8.- Noisy Neighborhood}

I know the phrase I don't know the phrase

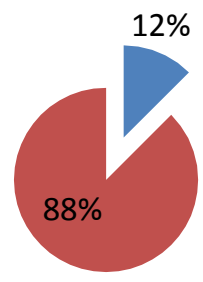

Image28: Noisy neighborhood

Source: 8 Graders from "Lenin School" Educative Unit

\section{INTERPRETATION:}

From eight evaluated students, 7 students say that they do not know the collocation noisy neighborhood corresponding to $88 \%$ while 1 student says that know the collocation corresponding to $12 \%$ of the sample.

\begin{tabular}{|l|l|}
\hline I know the phrase & 8 \\
\hline I don't know the phrase & 0 \\
\hline TOTAL & 8 \\
\hline
\end{tabular}

Table30: Tourist town

Source: 8 Graders from "Lenin School" Educative Unit

\section{9.- Tourist town}

I know the phrase I don't know the phrase

$0 \%$

$100 \%$

Image29: Tourist town

Source: 8 Graders from "Lenin School" Educative Unit 
INTERPRETATION:

From eight evaluated students, 8 students say that know the collocation tourist town corresponding to $100 \%$ of the sample.

\begin{tabular}{|l|l|}
\hline I know the phrase & 8 \\
\hline I don't know the phrase & 0 \\
\hline TOTAL & 8 \\
\hline
\end{tabular}

Table31: Strong bones

Source: 8 Graders from "Lenin School" Educative Unit

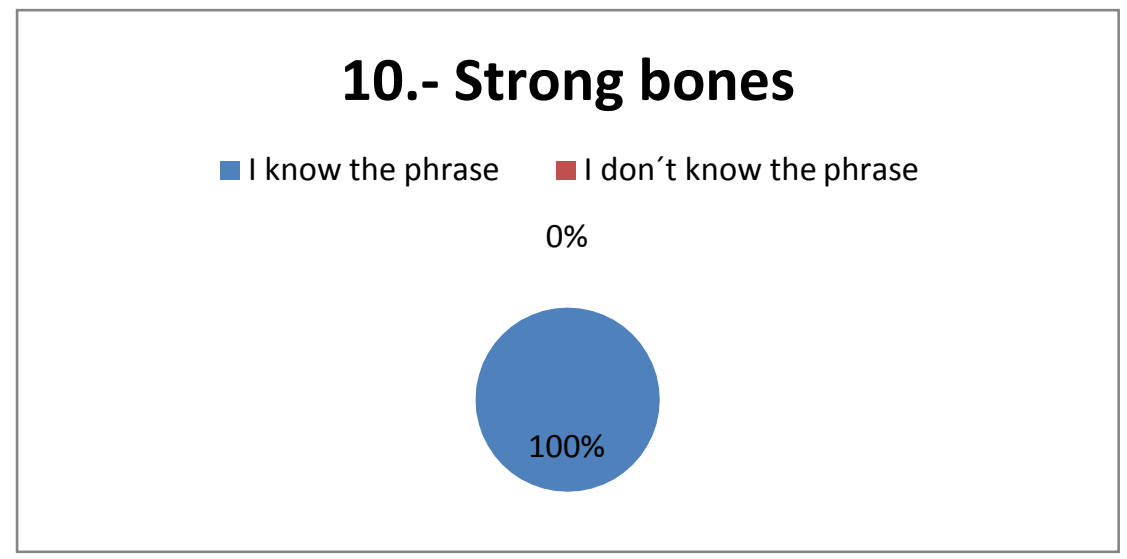

Image30: Strong bones

Source: 8 Graders from "Lenin School" Educative Unit

INTERPRETATION:

From eight evaluated students, 8 students say that know the collocation strong bones corresponding to $100 \%$ of the sample.

\begin{tabular}{|l|l|}
\hline I know the phrase & 7 \\
\hline I don't know the phrase & 1 \\
\hline TOTAL & 8 \\
\hline
\end{tabular}

Table32: Eat too

Source: 8 Graders from "Lenin School" Educative Unit 
Olga L. Gonzales-Ortiz; Raúl B. Cárdenas-Quintana; Marcia J. Chiluisa- Chiluisa

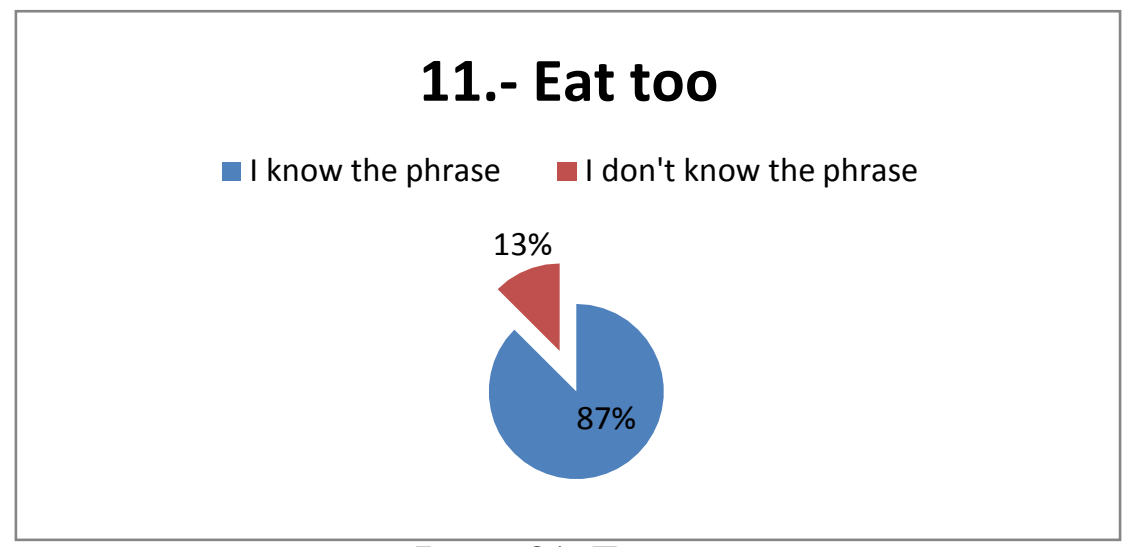

Image31: Eat too

Source: 8 Graders from "Lenin School" Educative Unit

INTERPRETATION:

From eight evaluated students, 1 student says that they do not know the collocation eat too corresponding to $13 \%$ while 7 students say that know the collocation corresponding to $87 \%$ of the sample.

\begin{tabular}{|l|l|}
\hline I know the phrase & 8 \\
\hline I don't know the phrase & 0 \\
\hline TOTAL & 8 \\
\hline
\end{tabular}

Table33: Nice trip

Source: 8 Graders from "Lenin School" Educative Unit

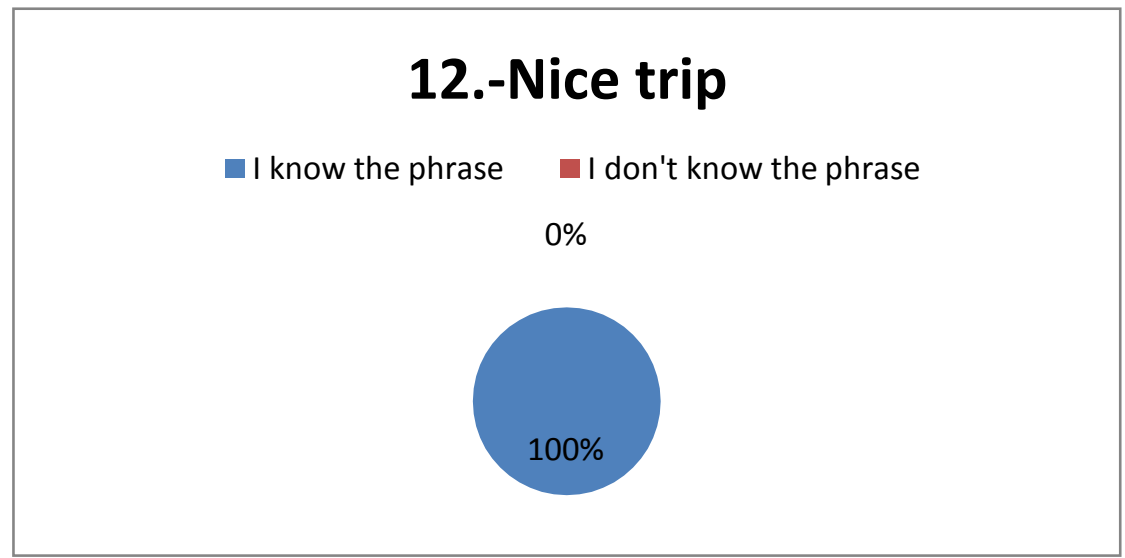

Imagr32: Nice trip

Source: 8 Graders from "Lenin School" Educative Unit 
INTERPRETATION:

From eight evaluated students, 8 students say that know the collocation nice trip corresponding to $100 \%$ of the sample.

\begin{tabular}{|l|l|}
\hline I know the phrase & 8 \\
\hline I don't know the phrase & 0 \\
\hline TOTAL & 8 \\
\hline
\end{tabular}

Table34: Come here

Source: 8 Graders from "Lenin School" Educative Unit

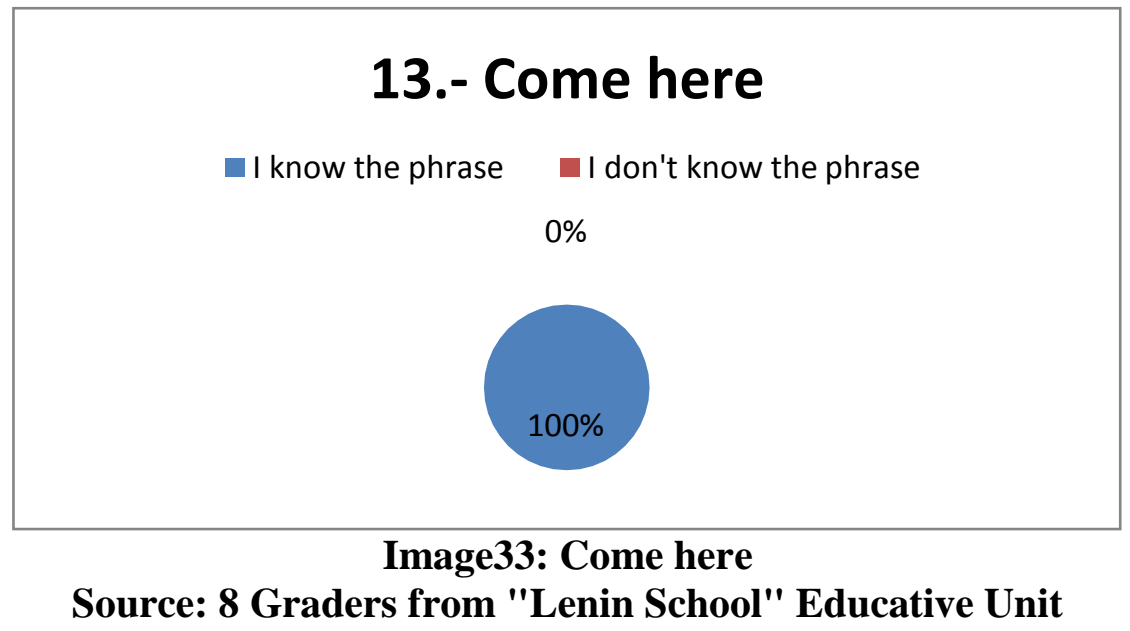

INTERPRETATION:

From eight evaluated students, 8 students say that know the collocation come here corresponding to $100 \%$ of the sample.

\begin{tabular}{|l|l|}
\hline I know the phrase & 3 \\
\hline I don't know the phrase & 5 \\
\hline TOTAL & 8 \\
\hline
\end{tabular}

Table35: Warm clothes

Source: 8 Graders from "Lenin School" Educative Unit 


\section{4.- Warm clothes}

I know the phrase $\quad$ I don't know the phrase

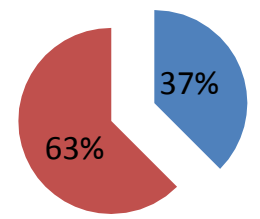

Image34: Warm clothes

Source: 8 Graders from "Lenin School" Educative Unit

\section{INTERPRETATION:}

From eight evaluated students, 5 students say that they do not know the collocation warm clothes corresponding to $63 \%$ while 3 students say that know the collocation corresponding to $37 \%$ of the sample.

\begin{tabular}{|l|l|}
\hline I know the phrase & 8 \\
\hline I don't know the phrase & 0 \\
\hline TOTAL & 8 \\
\hline
\end{tabular}

Table36: Christmas present

Source: 8 Graders from "Lenin School" Educative Unit

\section{5.- Christmas present}

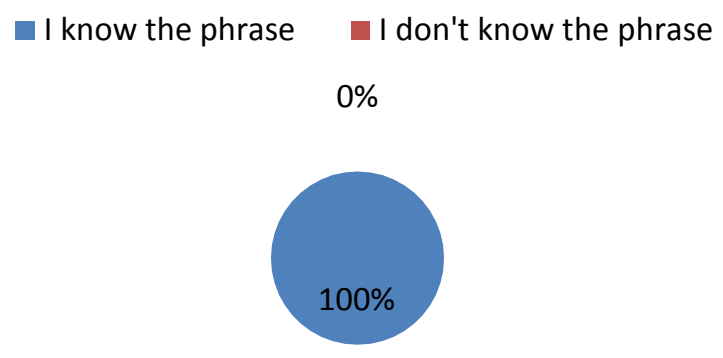

Image35: Christmas present

Source: 8 Graders from "Lenin School" Educative Unit 
INTERPRETATION:

From eight evaluated students, 8 students say that know the collocation christmas present corresponding to $100 \%$ of the sample.

\begin{tabular}{|l|l|}
\hline I know the phrase & 8 \\
\hline I don't know the phrase & 0 \\
\hline TOTAL & 8 \\
\hline
\end{tabular}

Table37: Exchange presents

Source: 8 Graders from "Lenin School" Educative Unit

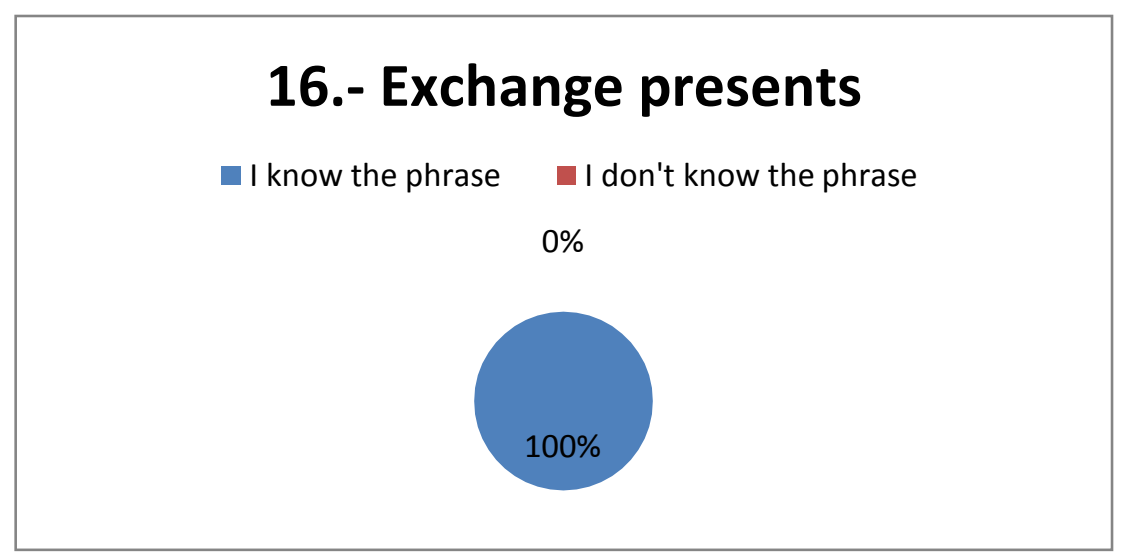

Image36: Exchange presents

Source: 8 Graders from "Lenin School" Educative Unit

INTERPRETATION:

From eight evaluated students, 8 students say that know the collocation exchange presents corresponding to $100 \%$ of the sample.

\begin{tabular}{|l|l|}
\hline I know the phrase & 8 \\
\hline I don't know the phrase & 0 \\
\hline TOTAL & 8 \\
\hline
\end{tabular}

Table38: Free time

Source: 8 Graders from "Lenin School" Educative Unit 


\section{7.- Free time}

I know the phrase I don't know the phrase

$0 \%$

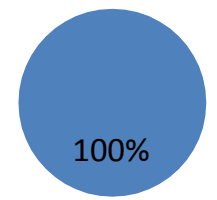

Image37: Free time

Source: 8 Graders from "Lenin School" Educative Unit

INTERPRETATION:

From eight evaluated students, 8 students say that know the collocation free time corresponding to $100 \%$ of the sample.

\begin{tabular}{|l|l|}
\hline I know the phrase & 8 \\
\hline I don't know the phrase & 0 \\
\hline TOTAL & 8 \\
\hline
\end{tabular}

Table39: Under water

Source: 8 Graders from "Lenin School" Educative Unit

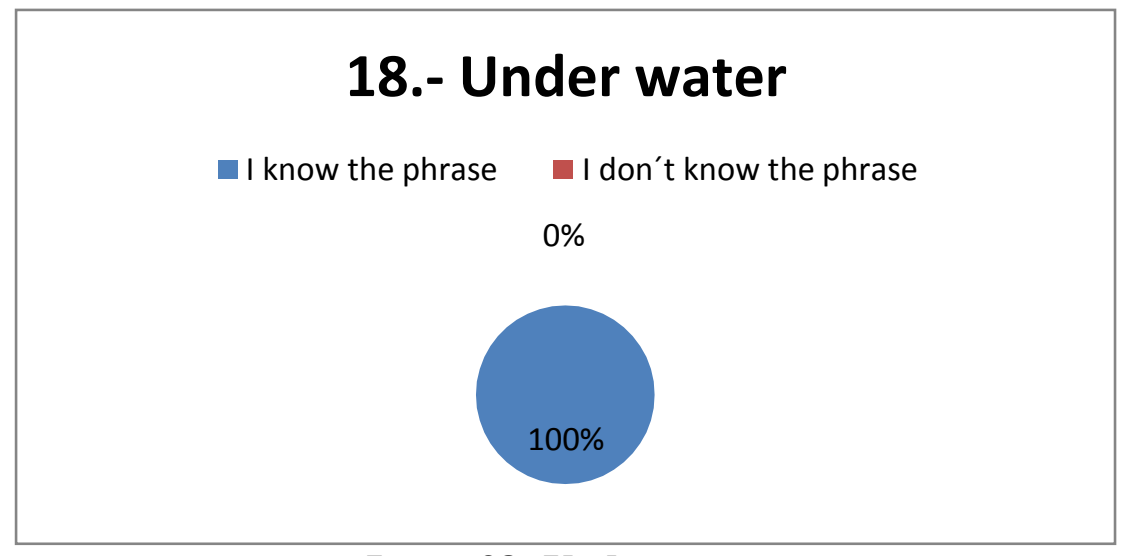

Image38: Under water

Source: 8 Graders from "Lenin School" Educative Unit 
INTERPRETATION:

From eight evaluated students, 8 students say that know the collocation under water corresponding to $100 \%$ of the sample.

\begin{tabular}{|l|l|}
\hline I know the phrase & 8 \\
\hline I don't know the phrase & 0 \\
\hline TOTAL & 8 \\
\hline
\end{tabular}

Table40: True friend

Source: 8 Graders from "Lenin School" Educative Unit

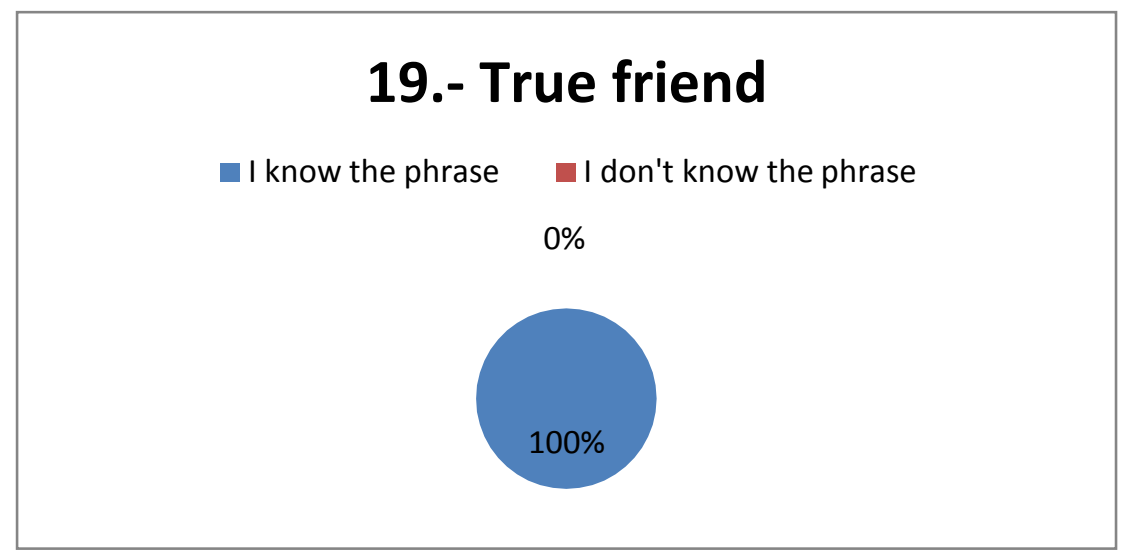

Image39: True friend

Source: 8 Graders from "Lenin School" Educative Unit

INTERPRETATION:

From eight evaluated students, 8 students say that know the collocation true friend corresponding to $100 \%$ of the sample.

\begin{tabular}{|l|l|}
\hline I know the phrase & 3 \\
\hline I don't know the phrase & 5 \\
\hline TOTAL & 8 \\
\hline
\end{tabular}

Table41: Human voice

Source: 8 Graders from "Lenin School" Educative Unit 


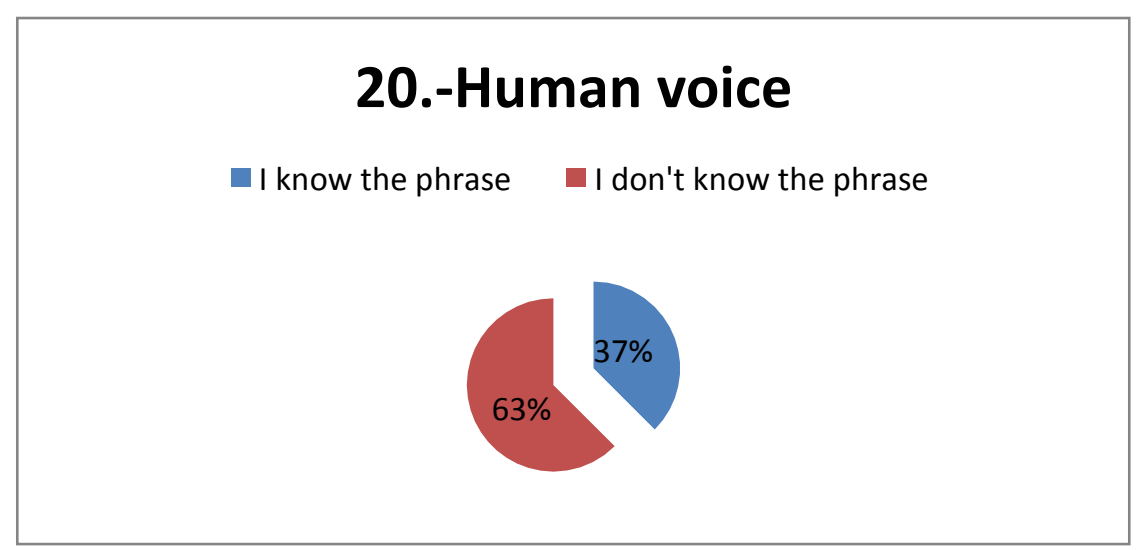

\section{Image40: Human voice}

Source: 8 Graders from "Lenin School" Educative Unit

\section{INTERPRETATION:}

From eight evaluated students, 5 students say that they do not know the collocation human voice corresponding to $63 \%$ while 3 students say that know the collocation corresponding to $37 \%$ of the sample.

\section{Conclusiones.}

The present investigation results so beneficial because with the use of lexical collocations. It is possible to maximize vocabulary learning. Moreover, teachers have the opportunity to use a new trend into teaching learning process so that improve their teaching methodology with this new approach. On the other hand, it tries to detect students' needs to develop speaking skill in order to students can improve in vocabulary knowledge also they can use their basic vocabulary and combines words so that use them into sentences easier and at the same time students practice speaking according the topic in their books. As a result, students are able to have a good communication in a fluent way. 


\section{Bibliografía.}

Biskri, Y. (2012). The Effect of Lexical Collocation. 69.

Dickinson, P. (2008). Raising awareness of collocation in the Japanese EFL classroom. Assignment submitted for Master of Arts in Applied Linguistics, 6-7-8.

Digest., E. (2001). Lexical Approach to Second Language Teaching. ERIC Digest. , 4-5.

Farrokh, P. (2012). Raising Awareness of Collocation in ESL/EFL. Journal of Studies in Education, 15.

Farrokh, P. (2012). Raising Awareness of Collocation in ESL/EFL. Journal of Studies in Education, 4.

Lexis, V. (2016). Vocabulary versus Lexis. Obtenido de Vocabulary versus Lexis: file:///C:/Users/EDWIN/Downloads/Vocabulary+Versus+Lexis\%20(3).pdf

Lexis, V. v. (s.f.). Vocabulary versus Lexis. 1.

Moudraia, O. (2001). Lexical Approach to Second Language Teaching. ERIC Digest. ERIC Digest., 2.

Nasser, M. (2015). The Use of Grammatical Collocations by Advanced Saudi EFL. International Journal of English Linguistics, 1.

Park, S. (2003). Lexical collocation use. 6-7-8.

Wang, T., \& L, R. (2008). CORPUSSTUDY OF VERB - NOUN LEXICAL. CELEA Journal (Bim onthly)

Ricoy, María-Carmen; Álvarez-Pérez, Sabela (2016). La Enseñanza del Inglés en la Educación Básica de Personas Jóvenes y Adultas. Distrito Federal-Mexico: Revista Mexicana de Investigación Educativa. 21(69)

Catalán, R. M. (2016). Vocabulary Profiles In English As A Foreign Language At The End Of Spanish Primary And Secondary Education. Concepcion: Scielo.

Kendler, M. D. (2007). The Impact of Teaching Methodologies on the Effectiveness of English Language Learning. Maracaibo-Venezuela: Redalyc.

L, C. D., I., P. M., G., I. R., \& J., M. G. (2010). La Enseñanza Y Aprendizaje Del Inglés En El Aula: Una Mirada A Las Cogniciones Pedagógicas De Un Grupo De Jóvenes Estudiantes De Pedagogía. Caracas-Venezuela: Redalyc.

Patarroyo, L. M. (2011). Teaching English In Times Of The National Bilingua Program In Some State Schools: Linguistic And Pedagogical Factors. . Bogota-Colombia: Redalyc.

Quintero, D. J. (2006). Contextos Culturales En El Aula De Inglés. Medellin-Colombia: Redalyc. 